\title{
Incidence of Viruses Infecting Tomato and Their Natural Hosts in the Southeast and Central Regions of Iran
}

\author{
Hossain Massumi, Department of Environmental Science, International Center for Sciences High Technology and \\ Environmental Science, Kerman, Iran, and Department of Plant Pathology, College of Agriculture, Shahid Bahonar \\ University of Kerman, P.O. Box 76169-133, Kerman, Iran; Mehdi Shaabanian, Akbar Hosseini Pour, and \\ Jahangir Heydarnejad, Department of Plant Pathology, College of Agriculture, Shahid Bahonar University of Ker- \\ man, P.O. Box 76169-133, Kerman, Iran; and Heshmetollah Rahimian, Department of Plant Pathology, College of \\ Agriculture, Mazandaran University, Sari, Mazandaran, Iran
}

\begin{abstract}
Massumi, H., Shaabanian, M., Hosseini Pour, A., Heydarnejad, J., and Rahimian, H. 2009. Incidence of viruses infecting tomato and their natural hosts in the southeast and central regions of Iran. Plant Dis. 93:67-72.

A survey was conducted to determine the incidence of Cucumber mosaic virus (CMV), Beet curly top virus (BCTV), Tomato yellow leaf curl virus (TYLCV), Tomato chlorotic spot virus (TcSV), Potato virus Y (PVY), Potato virus S (PVS), Tomato spotted wilt virus (TSWV), Tomato ringspot virus (TRSV), Tomato aspermy virus (TAV), Arabis mosaic virus (ArMV), Tobacco streak virus (TSV), Tomato bushy stunt virus (TBSV), Tobacco mosaic virus (TMV), and Tomato mosaic virus (ToMV) on tomato (Solanum lycopersicum) in the major horticultural crop growing areas in the southeast and central regions of Iran. A total of 1,307 symptomatic leaf samples from fields and 603 samples from greenhouses were collected from January 2003 to July 2005 in five southeastern and central provinces of Iran. Samples of symptomatic plants were analyzed for virus infection by enzyme-linked immunosorbent assay (ELISA) using specific polyclonal antibodies. ArMV and CMV were the most frequently found viruses, accounting for 25.6 and $23.4 \%$, respectively, of the collected samples. BCTV, TSWV, TMV, PVY, ToMV, and TYLCV were detected in $6.1,5.8,5.6,5,4.8$, and $1.6 \%$ of the samples, respectively. TBSV, TAV, TSV, PVS, and TRSV were not detected in any of the samples tested. Double and triple infections involving different combination of viruses were found in 13.9 and $1.7 \%$ of samples, respectively. This is the first report of PVY and ArMV as viruses naturally infecting tomato in Iran. Infection of tomato plants with PVY and ArMV was confirmed. Six out of 20 plant species belonging to six genera, growing in tomato fields or in the nearby areas, were found infected with TSWV, TMV, PVY, and CMV.
\end{abstract}

Additional keywords: RT-PCR, serological testing

Tomato (Solanum lycopersicum L.) is an important vegetable crop grown on approximately 130,000 ha, and with an estimated production of 4, $200 \mathrm{Mt}$ (17) in Iran. About $80 \%$ of tomato production is fieldgrown, and the rest is produced in greenhouses. There has been an increasing trend in Iran toward production of tomatoes under plastic covers or in greenhouses over the past few years.

Virus diseases are one of the most important problems facing growers in Iran. About 25 different viruses are reported on tomato worldwide (28). Some of the most important viruses infecting tomatoes naturally are: Cucumber mosaic virus (CMV) $(1,18)$, Tomato mosaic virus (ToMV) (52),

Corresponding author: H. Massumi

E-mail: masoomi@mail.uk.ac.ir

Accepted for publication 22 September 2008.

doi:10.1094/PDIS-93-1-0067

(C) 2009 The American Phytopathological Society
Tomato yellow leaf curl virus (TYLCV) (40), Tomato spotted wilt virus (TSWV) $(6,50)$, Beet curly top virus (BCTV) $(8,23)$, Tobacco mosaic virus (TMV) (39), and Potato virus $Y$ (PVY) (5). Many others, including Tomato chlorotic spot virus (TcSV) (50), Potato virus $S$ (PVS) (31), Tomato ringspot virus (TRSV) (47), Tomato aspermy virus (TAV) (25), Tobacco streak virus (TSV) (45), Tomato bushy stunt virus (TBSV) (38), and Arabis mosaic virus (ArMV) (51), are also damaging to tomato.

Tomato is grown as a summer crop in most areas of Iran; however, in the subtropical regions of the country in the southeast (Kerman, Hormozgan, and Boushehr provinces), which are frost-free in winter, tomato is also grown as a winter crop. Almost continuous year-round cultivation of tomato in these areas during the past several years has possibly contributed to the widespread incidence of virus diseases affecting this crop. Limited information is available on the occurrence and the relative importance of viruses infecting tomatoes in this major tomato growing area of the country; only ToMV and TYLCV have been reported from tomato in Hormozgan and Sistan-Baluchestan $(2,7,22)$. In other regions of Iran, Alfalfa mosaic virus (AMV), CMV, ToMV, TSWV, Potato chlorotic stunt virus (PCSV), and Eggplant mottled dwarf virus (EMDV) are known to occur in fieldgrown tomatoes $(1,2,6,13,19,30)$. Therefore, a survey encompassing the major tomato growing regions of southeastern and central Iran was conducted from January 2003 to July 2005, to determine the incidence and relative importance of CMV, BCTV, TYLCV, TcSV, PVY, PVS, TSWV, TRSV, TAV, ArMV, TSV, TBSV, TMV, and ToMV in tomato fields and greenhouses. In addition, weed species growing in and around tomato fields and greenhouses, and suspected of playing a role in perpetuation and over-seasoning of the viruses in the absence of the crop, were collected and assayed for infection by the viruses.

\section{MATERIALS AND METHODS}

Surveys and sample collection. Samples of tomato and weed species were collected from January 2003 to July 2005 from tomato fields and greenhouses in Kerman (Jiroft, Kahnuj, and Zarand areas), Hormozgan (Minabe and Hajiabad areas), Sistan-Baluchestan (Khash and Iran-shahr areas), Yazd (Yazd city), and Boushehr (Borazjan district) provinces (Table 1). Surveys were made about 120 days after planting. Samples composed of young leaves or terminal growth were collected from plants that showed symptoms typical of virus infections. Samples of symptomless weeds growing within and near tomato fields in the Jiroft, Boushehr, Minabe, and Yazd regions were also collected.

Virus identification. Each plant sample was placed separately in a plastic bag and kept on ice until analyzed. The presence of TMV, TcSV, ArMV, PVY, TBSV, TAV, TSV, and TRSV was determined using the double antibody sandwich enzyme-linked immunosorbent assay (DASELISA; 12). The incidence of TSWV and TYLCV was determined using triple antibody sandwich ELISA (TAS-ELISA), which was performed according to De 
Avila et al. 1990 (14). CMV, PVS, ToMV, and BCTV were detected by the platetrapped antigen (PTA)-ELISA (35).

Antisera to TYLCV, TBSV, TcSV, TAV, and TSV and the positive virus controls were purchased from DSMZ (Braunschweig, Germany). Antisera and the positive and negative virus controls for PVY, TMV, TSWV, TRSV, and ArMV were obtained from Bioreba (Reinach, Switzerland). CMV, PVS, and ToMV antisera were provided by $\mathrm{P}$. Jones (IACRRothamsted, Harpenden, Herts, UK). BCTV-antiserum and the positive control sample were kindly provided by K. Izadpanaeh (Shiraz University, Shiraz, Iran). Iranian isolates of CMV, PVS, and ToMV maintained on tomato and potato (PVS) plants in the greenhouse were also employed as positive control samples. Leaves of healthy tomato cv. Rutgers seedlings grown from certified seeds in the greenhouse were used as negative controls for TYLCV, TBSV, TcSV, TAV, BCTV, CMV, PVS, PVY, TMV, TSWV, TRSV, ArMV, ToMV, and TSV in all ELISAs.

TAS-ELISA was carried out in the following steps: coating the plates with immunoglobulin G (IgG) from polyclonal antibodies (PAbs); adding plant extracts; use of respective monoclonal antibodies (MAbs) for the TSWV or TYLCV; and coating with goat-antirabbit IgG conjugated to alkaline phosphatase (Sigma Chemical Co., St. Louis, MO, USA) (14).

For DAS-ELISA, plates were coated with $100 \mu \mathrm{l}$ of each $\mathrm{IgG}$ diluted 1:1,000 in carbonate coating buffer $\left(0.6 \mathrm{M} \mathrm{Na}_{2} \mathrm{CO}_{3}\right.$ and $0.14 \mathrm{M} \mathrm{NaHCO}, \mathrm{pH}$ 9.6), and the assays were carried out according to manufacturer's instructions (Bioreba).

PTA-ELISA was used as described by Mowat and Dawson (35), with some modification. Briefly, test samples diluted 1:20 in $0.05 \mathrm{M}$ carbonate buffer, $\mathrm{pH} 9.6$, were added to wells of flat-bottom Nunc Maxisorb microtiter ELISA plates and incubated for $2 \mathrm{~h}$ at $37^{\circ} \mathrm{C}$ (Bioreba). Polyclonal antisera diluted 1:500 in $0.2 \mathrm{M}$ Tris- $\mathrm{HCl}$ buffer, $\mathrm{pH} 7.2$, were added to the wells, and the plate was incubated for $2 \mathrm{~h}$ at $37^{\circ} \mathrm{C}$. Goat-antirabbit $\mathrm{IgG}$ conjugated to alkaline phosphatase, diluted 1:2,000 in Tris- $\mathrm{HCl}$ buffer, was added to the plate and incubated as before. After addition of $p$ nitrophenyl phosphate $(5 \mathrm{mg} / \mathrm{ml}$ in $10 \%$ diethanolamine) and incubation for $1 \mathrm{~h}$ at room temperature, color reactions for DAS-ELISA, PTA-ELISA, and TASELISA were measured at $405 \mathrm{~nm}$ using an ELISA reader (EL800; Bio-Tek Instruments, Winooski, VT, USA). Positive and negative controls were included in all tests for each virus, respectively. A sample was considered virus-positive if its OD exceeded the mean plus three standard deviations of the OD of the healthy controls.

Sap from the weed samples that tested positive for TMV, PVY, CMV, and TSWV were inoculated on Nicotiana tabacum cv. Samsun NN., N. glutinosa L., Cucurbita pepo L., and Datura stramonium L. plants, respectively, to confirm the identity of the viruses based on symptomatology on selected hosts. Inoculations were made using leaf extracts prepared in $0.05 \mathrm{M}$ potassium phosphate buffer, $\mathrm{pH}$ 7.5, containing $0.0013 \mathrm{M}$ EDTA, $0.01 \% \mathrm{Na}_{2} \mathrm{SO}_{3}$, and $2 \%$ polyvinylpyrrolidone. At least three plants of each species or cultivar were mechanically inoculated. After inoculation, plants were kept in an insect-proof greenhouse at 15 to $25^{\circ} \mathrm{C}$ for symptom development. ELISA was used as well as symptomology to check for presence of the respective viruses in inoculated plants.

Polymerase chain reaction (PCR) primers. Forward and reverse primers ArMV-F and ArMV-R (Table 2) were designed by alignment of available ArMV sequences, including GenBank accession numbers AB279739, AB279741, AB279740, and NC006056. Sequences of ArMV-F and ArMV-R primers corresponded to nucleotides 247-268 and 10291050 of the ArMV isolate NW (accession number AY017339), respectively. Two primers (F11 and R11) described by Boonham et al. (9) were used to amplify to all PVY strains.

RNA isolation, reverse transcription, and PCR. Infected plant tissues were ground in $0.1 \mathrm{M}$ ammonium citrate buffer (ACB), $\mathrm{pH} 6.5$, treated by $30 \%$ chloroform, and centrifuged at $8,000 \mathrm{rpm}$ for 10 min. Viral RNA was captured from supernatant using the mRNA capture kit (Roche, Mannheim, Germany). The reverse transcription reaction was carried out by using RNasin ribonuclease inhibitor (Promega, Madison, WI, USA), Moloney Murine Leukemia Virus reverse transcriptase (MMLV RT, Gibco-BRL, Gaithersburg, MD, USA), and the reverse primer for each of

Table 1. Occurrence of viruses on tomato cultivars with viruslike symptoms collected from regions in southeast and central of Iran from January 2003 to July 2005

\begin{tabular}{|c|c|c|c|c|c|c|c|c|c|c|c|c|c|}
\hline \multirow[b]{2}{*}{ Province } & \multirow[b]{2}{*}{ Region } & \multirow{2}{*}{$\begin{array}{c}\text { No. } \\
\text { surveyed }\end{array}$} & \multicolumn{4}{|c|}{ DAS-ELISA ${ }^{a}$} & \multicolumn{3}{|c|}{ PTA-ELISA $^{\text {b }}$} & \multicolumn{2}{|c|}{ TAS-ELISA $^{c}$} & \multicolumn{2}{|c|}{ Infection } \\
\hline & & & TMV & PVY & TeSV & ArMV & ToMV & BCTV & CMV & TSWV & TYLCV & Double & Triple \\
\hline & Jiroft & 310 & $0 / 310^{\mathrm{d}}$ & $14 / 310$ & $0 / 310$ & $104 / 310$ & $7 / 310$ & ND & $50 / 310$ & $28 / 310$ & ND & $6 / 310$ & $0 / 310$ \\
\hline \multirow[t]{2}{*}{ Kerman } & Kahnuj & 91 & $0 / 91$ & $0 / 91$ & $0 / 91$ & $31 / 91$ & $0 / 91$ & $0 / 91$ & $0 / 91$ & $33 / 91$ & ND & $18 / 91$ & $0 / 91$ \\
\hline & Zarand & 278 & $0 / 278$ & $23 / 278$ & $0 / 278$ & $26 / 278$ & $0 / 278$ & $62 / 278$ & $8 / 278$ & $0 / 278$ & $0 / 278$ & $10 / 278$ & $0 / 278$ \\
\hline \multirow[t]{2}{*}{ Hormozgan } & Minabe & 365 & $81 / 365$ & $0 / 365$ & $0 / 365$ & $95 / 365$ & $73 / 365$ & $4 / 365$ & $64 / 365$ & $19 / 365$ & ND & $63 / 365$ & $0 / 365$ \\
\hline & Haji abad & 132 & $4 / 132$ & $0 / 132$ & $0 / 132$ & $27 / 132$ & $0 / 132$ & ND & $0 / 132$ & $0 / 132$ & $0 / 132$ & $2 / 132$ & $0 / 132$ \\
\hline \multirow{2}{*}{$\begin{array}{l}\text { Sistan- } \\
\text { Baluchestan }\end{array}$} & Khash & 169 & $0 / 169$ & $23 / 169$ & $0 / 169$ & $20 / 169$ & $5 / 169$ & $18 / 169$ & $19 / 169$ & $12 / 169$ & $18 / 169$ & $9 / 169$ & $3 / 169$ \\
\hline & Iran-s & 140 & $15 / 140$ & $15 / 140$ & $0 / 140$ & $31 / 140$ & $0 / 140$ & $0 / 140$ & $80 / 140$ & $4 / 140$ & $0 / 140$ & $32 / 140$ & $8 / 140$ \\
\hline Yazd & Yazd & 274 & $7 / 274$ & $20 / 274$ & $0 / 274$ & $121 / 274$ & $0 / 274$ & $0 / 274$ & $157 / 274$ & $15 / 274$ & $0 / 274$ & $121 / 274$ & $22 / 274$ \\
\hline Boushehr & Borazjane & 151 & $0 / 151$ & $0 / 151$ & $4 / 151$ & $33 / 151$ & $7 / 151$ & ND & $52 / 151$ & $0 / 151$ & ND & $4 / 151$ & $0 / 151$ \\
\hline Total & & 1,910 & $107 / 1,910$ & $95 / 1,910$ & $4 / 1,910$ & $488 / 1,910$ & $92 / 1,910$ & $84 / 1,381$ & $447 / 1,910$ & $111 / 1,910$ & $18 / 1,124$ & $265 / 1,910$ & $33 / 1,910$ \\
\hline Percent & & $\ldots$ & 5.6 & 5 & 0.2 & 25.6 & 4.8 & 6.1 & 23.4 & 5.8 & 1.6 & 13.9 & 1.7 \\
\hline
\end{tabular}

${ }^{a}$ Double antibody sandwich enzyme-linked immunosorbent assay (DAS-ELISA) for Tomato mosaic virus (TMV), Potato virus Y (PVY), Tomato chlorotic spot virus (TcSV), and Arabis mosaic virus (ArMV).

b Plate-trapped antigen (PTA)-ELISA for Tobacco mosaic virus (ToMV), Beet curly top virus (BCTV), and Cucumber mosaic virus (CMV).

c Triple antibody sandwich (TAS)-ELISA for Tomato spotted wilt virus (TSWV) and Tomato yellow leaf curl virus (TYLCV).

${ }^{\mathrm{d}}$ Number of infected plants/number of plants sampled. ND $=$ not determined.

Table 2. Primers used to amplify coat protein $(\mathrm{CP})$ or $\mathrm{P} 1$ gene sequences of the two viruses

\begin{tabular}{|c|c|c|c|c|}
\hline Viruses $^{\mathbf{a}}$ & Primers & Primer sequences $5^{\prime}-\mathbf{3}^{\prime}$ & Region amplified & Genomic location \\
\hline \multirow[t]{2}{*}{ ArMV } & ArMV-F & TTA ATT TCT CTG CCC GCA AGG & Protein $2 \mathrm{~A}$ & $247-268$ \\
\hline & ArMV-R & TRG CAG CCR TTC CCA SCC AGG & & $1029-1050$ \\
\hline \multirow[t]{2}{*}{ PVY } & F11 & RGCYTTCACTGAAATGATGG & $\begin{array}{l}\text { Nuclear inclusion pro- } \\
\text { tein (NIb) gene }\end{array}$ & $8460-8481$ \\
\hline & R11 & AACTGGAAGAATTGGCGGCCGCAGGAATTTTTTTTTTTTTTTTTT & Poly A tail & $9270-9670$ \\
\hline
\end{tabular}

\footnotetext{
a ArMV = Arabis mosaic virus PVY $=$ Potato virus $Y$.
} 
two PVY and ArMV, individually (Table 2). The PCR reaction was different according to the primer pair used. With the PVY primer pair, $2 \mu \mathrm{l}$ of the reverse transcription reaction was amplified in a total volume of $25 \mu$ containing $2 \mathrm{mM} \mathrm{MgCl} 2,0.4$ $\mathrm{mM}$ of each dNTPs, $0.4 \mu \mathrm{M}$ of each primer, and 0.6 units of Taq DNA polymerase (Perkin-Elmer, Norwalk, CT, USA) in the buffer recommended by the manufacturer. The PCR mix was subjected to an initial denaturation at $92^{\circ} \mathrm{C}$ for $5 \mathrm{~min}$ in a TC-312 (Techne, Cambridge, UK) PCR Express, followed by 30 cycles of $92^{\circ} \mathrm{C}$ denaturation for $1 \mathrm{~min}, 57^{\circ} \mathrm{C}$ annealing for $1 \mathrm{~min}$, and $72^{\circ} \mathrm{C}$ elongation for $1 \mathrm{~min}$ and further extension for $5 \mathrm{~min}$ at $72^{\circ} \mathrm{C}$. With the ArMV-F/ArMV-R primer pair, $2.5 \mu \mathrm{l}$ of the reverse transcription reaction was amplified in a total volume of $25 \mu \mathrm{l}$ containing $1 \mathrm{mM} \mathrm{MgCl} 2,0.2 \mathrm{mM}$ of each dNTPs, $0.4 \mathrm{mM}$ of each primer, and 0.6 units of Taq DNA polymerase in the buffer recommended by the manufacturer. Finally, cycles of amplification in a TC-312 (Techne) PCR Express were carried out using the following program: $92^{\circ} \mathrm{C}$ for $3 \mathrm{~min}, 55^{\circ} \mathrm{C}$ annealing for $1 \mathrm{~min}, 72^{\circ} \mathrm{C}$ elongation for 1 $\mathrm{min}$, and further extension for $10 \mathrm{~min}$ at $72^{\circ} \mathrm{C}$.

\section{RESULTS}

Field and greenhouse symptoms. Infected tomato plants exhibited a variety of symptoms, including mottling, mild to severe mosaic, crinkling, vein clearing, distortion and twisting of leaves, bushy growth, leaf roll, along with interveinal or general chlorosis and yellowing. Symptoms due to virus infection and those caused by abiotic agents (insecticide, herbicide, and nutrient deficiencies) were observed in several fields and greenhouses. Incidence of symptomatic plants varied greatly, not only among regions but also among the cultivars of tomato.

Surveys for virus identification. Of 1,910 tomato leaf samples tested by the three methods of ELISA, ArMV was found in 488 samples (25.6\% incidence), CMV in $447(23.4 \%)$, BCTV in $84(6.1 \%)$, TSWV in $111(5.8 \%)$, TMV in $107(5.6 \%)$, PVY in $95(5 \%)$, ToMV in $92(4.8 \%)$, TYLCV in $18(1.6 \%)$, and TcSV in just 4 $(0.2 \%)$ of the samples. TBSV, TAV, TSV, PVS, and TRSV were not detected in any of the samples tested. Of the 14 viruses tested, ArMV was found in all of the regions surveyed. CMV, TSWV, PVY, TMV, ToMV, and BCTV were detected in 88.8, $66.6,55.6,44.4,44.4$, and $33 \%$ of the regions, respectively. TcSV and TYLCV were detected only in one region (11\%), in Boushehr and Sistan-Baluchestan provinces, respectively. However, tests for TYLCV were performed in five out of nine regions (Table 1), because antiserum to this virus was not available when the samplings were performed in the other four regions.
The symptoms produced in tomato leaves by TMV was a light- and dark-green mosaic pattern, twisting of leaves, and striking yellow mosaic. These symptoms were observed in CMV and ToMV infected tomato plants. But few plants infected by CMV showed shoestring leaf blade symptoms. Mottle symptoms caused by CMV were similar to those caused by ToMV. Symptoms of the TSWV disease in tomato typically included cupping and rolling of the upper leaves, which usually turned purple/brown along the veins. An internal spotting or browning of leaf tissue occurred frequently. The symptoms caused by PVY included interval chlorosis and yellowing of leaves. The leaves of tomato plants infected by BCTV were thicker and crisp and rolled upward as the petioles of the leaf rolled downward. Symptoms of TYLCV-infected plants included yellowing, leaf curling, and stunting. The symptoms of ArMV in tomato varied greatly in intensity depending upon the variety and possibly virus strain. The most characteristic symptom of the disease on leaves was mild to severe mosaic, interveinal yellowing, crinkling, and bright mottling.

Double virus infections were detected in $13.9 \%(265 / 1,910)$ of all samples that tested positive by ELISA. Among doubly infected plants, $153(8 \%)$ samples were infected with CMV and ArMV, the most frequently detected viruses. Double infections with TMV+ArMV, ToMV+CMV, TMV+CMV, TSWV+ArMV, TSWV+CMV, ArMV+PVY, CMV+PVY, and TMV+ BCTV accounted for 1.3, 0.7, 1, 0.4, 0.3, $0.2,0.2$, and $0.1 \%$ of the collected samples, respectively. Triple infections involving combinations of ArMV+CMV+PVY, TMV+ $\mathrm{CMV}+\mathrm{ArMV}$, and TSWV+ArMV+PVY were encountered in only 33 cases.

The symptoms of mixed infection in some cases such as ArMV+TMV included light- and dark-green mosaic patterns and blistering of the upper leaves. TSWV+ ArMV caused chlorotic spots on leaves of tomato plants and in some cases interveinal yellowing and chlorosis of leaves.
A

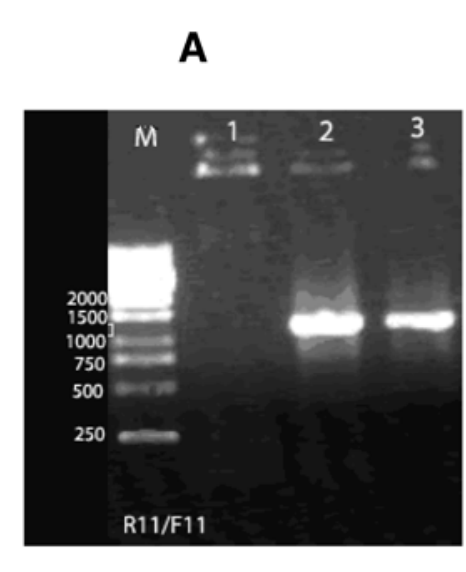

ToMV+CMV caused symptoms including shoestring and fern-leaf.

Detection of PVY and ArMV by RTPCR. RT-PCR was used to determine presence or absence of PVY and ArMV infected samples. RNA was purified using fragment was detected by RT-PCR with PVY primers when virus-infected samples were examined. Similarly, an approximately 800-bp fragment was detected when ArMV-infected samples were examined with ArMV-specific primers (Fig. 1).

Weed plants as hosts of tomato viruses. Assays showed that many species growing in and near tomato fields harbored TMV, PVY, CMV, and TSWV. Plants of six species in six genera belonging to six families were positive by ELISA for the above-mentioned viruses (Table 3). Three weed plants including Chrozophora heirosolymitana Spreng., Brassica sp., and Galium aparine L. were infected with TMV, CMV, and PVY, respectively. Furthermore, three other weed species including Chenopodium murale L., Heliotropium europaeum L., and Malva neglecta Wallr. were infected with double infection of TMV+TSWV, PVY+CMV, and CMV+ TSWV, respectively. Infection of weed plants with TMV, PVY, CMV, and TSWV was confirmed following mechanical inoculation to Nicotiana tabacum cv. Samsun NN., N. glutinosa, Cucurbita pepo, and Datura stramonium, respectively. TMV caused mild mosaic and vein clearing, followed by malformation of leaves on $N$. tabacum cv. Samsun NN. PVY produced mosaic and severe mottling on $N$. glutinosa. D. stramonium reacted with local induced chlorotic local lesions on the first true leaf 1 week after inoculation followed by mosaic and blistering of the other expanding leaves. Infection of the inoculated test plants with the respective viruses was confirmed by ELISA.

ArMV, TcSV, ToMV, PVS, BCTV, and TYLCV were not detected in any weed mRNA capture kit (Roche). A 1,200-bp lesions followed by mosaic symptoms to the presence of TSWV. On C. pepo, CMV

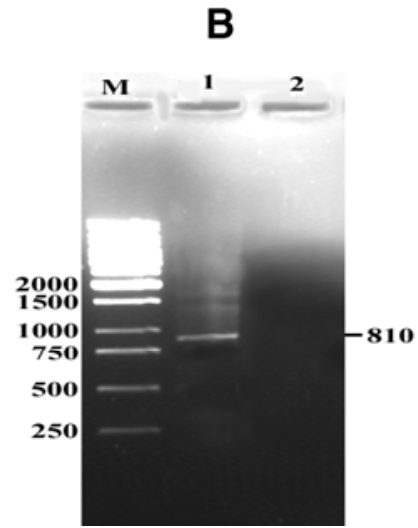

Fig. 1. Reverse transcription-polymerase chain reaction detection of Potato virus $Y$ (PVY) and Arabis mosaic virus (ArMV). A, Lane M, 1-kb DNA ladder; lane 2, healthy tomato; lanes 2 and 3, tomato with PVY; B, lane M, 1-kb DNA ladder; lane 1, tomato with ArMV; lane 2, healthy tomato. 
species tested. TMV, PVY, CMV, and TSWV also could not be detected by ELISA or through mechanical inoculation in plants of 12 species from nine families growing inside or in the nearby areas of tomato fields (Table 3). All weed species found to be infected with TMV, PVY, CMV, or TSWV, as determined by ELISA and mechanical inoculation tests, were symptomless.

\section{DISCUSSION}

Viruses have always been a major cause of reduced quantity and quality of the worldwide tomato crop (28). In Iran, high incidence of viruslike symptoms is often observed on tomato plants. In the present study, the incidence and distribution of 14 viruses in tomato fields and greenhouses in the southeast and central regions of Iran is documented.

Nine viruses were found infecting tomatoes, with ArMV being the most widespread virus. Although CMV is one of the most important viruses infecting tomatoes in some areas of Iran and elsewhere (1), ArMV appears to be the most prevalent virus in the central and southeastern regions, where tomato is grown almost yearround. CMV was widespread in many regions. Its incidence varied from high in Yazd and Iran-shahr to moderate in Minabe and Borzjane, and to low in Jiroft,
Kahnuj, and Khash. Incidence of CMV was high in several other crops throughout the country $(21,46)$.

ArMV was first reported in 2004 infecting a few grapevine plants in a few regions in Iran (41). The virus was subsequently detected in grapevine and rose plants $(43,44)$. This virus was found in a considerable number of the tomato samples $(488 / 1,910)$ from different regions in southeastern and central Iran, whereas the incidence of PVY was very low $(95 / 1,910)$ in most of the areas surveyed. These two viruses are being reported for the first time from Iran. The presence of ArMV and PVY in selected samples was confirmed by RT-PCR. The high incidence of ArMV may be related in part to its extremely wide host range, which consists of more than 93 plant species (36). Nevertheless, with the exception of tomato, grapevine, and rose, other hosts have not been reported for ArMV in Iran. Xiphinema diversicaudatum and $X$. index are vector nematode species of ArMV and Grapevine fanleaf virus (GFLV) (27). According to Fadaei (16), fields and greenhouses growing tomato in Iran were severely infected with $X$. index. Therefore, the high incidence of ArMV in tomato fields and greenhouses is possibly due to the presence of its nematode vector.
Two tospoviruses, TSWV and TcSV, were encountered in this survey. To our knowledge, TcSV has not been reported from Iran before, but based on ELISA results, four samples from the Borazjane region tested positive for TcSV. Further research will be necessary to confirm the presence of this virus in Iran using additional methods. TcSV, which is efficiently transmitted by the thrips species Frankliniella occidentalis (Perg.) and $F$. schultzei, is prevalent in tropical and subtropical regions (49) and has been reported in Brazil, South Africa, and Argentina (15). Boushehr province has a semitropical climate which would allow persistence of $\mathrm{TcSV}$ and its thrips vectors.

The occurrence of TSWV on tomato was first reported from Varamin, Tehran province (6). TSWV is transmitted by Thrips tabaci Lindeman, and possibly other species of thrips such as T. setosus, Scirtothrips dorsalis, and F. occidentalis $(4,29,48,50)$. The presence of several species of thrips may provide conditions for the high incidence of TSWV on tomato. TSWV has also been reported to infect tomato naturally in many countries such as Argentina, Bulgaria, and Finland $(26,32,50)$.

TYLCV has previously been reported from Kerman, Hormozgan, and Sistan-

Table 3. Infection of selected weed species by viruses that infect tomato

\begin{tabular}{|c|c|c|c|c|c|c|}
\hline \multirow[b]{2}{*}{ Family, species } & \multirow[b]{2}{*}{ Common name } & \multirow[b]{2}{*}{ No. of samples } & \multicolumn{4}{|c|}{ Virus $^{\mathbf{a}}$} \\
\hline & & & TMV & PVY & CMV & TSWV \\
\hline \multicolumn{7}{|l|}{ Euphorbiaceae } \\
\hline Chrozophora hierosolymitana Spreng. & Turnsole & 16 & $2 / 16$ & $0 / 16$ & $0 / 16$ & $0 / 16$ \\
\hline C. gracilis Fisch \& Hey & Turnsole & 4 & $0 / 4$ & $0 / 4$ & $0 / 4$ & $0 / 4$ \\
\hline Euphorbia granulate Forssk. & Euphorbia & 2 & $0 / 2$ & $0 / 2$ & $0 / 2$ & $0 / 2$ \\
\hline \multicolumn{7}{|l|}{ Portulacaceae } \\
\hline Portulaca oleracea L. & Common purslane & 8 & $0 / 8$ & $0 / 8$ & $0 / 8$ & $0 / 8$ \\
\hline \multicolumn{7}{|l|}{ Solanaceae } \\
\hline Physalis alkekengi $\mathrm{L}$. & Strawberry ground cherry & 2 & $0 / 2$ & $0 / 2$ & $0 / 2$ & $0 / 2$ \\
\hline \multicolumn{7}{|l|}{ Plantaginaceae } \\
\hline Plantago major L. & Plantain & 2 & $0 / 2$ & $0 / 2$ & $0 / 2$ & $0 / 2$ \\
\hline \multicolumn{7}{|l|}{ Amaranthaceae } \\
\hline Amaranthus retroflexus $\mathrm{L}$. & Redroot pigweed & 6 & $0 / 6$ & $0 / 6$ & $0 / 6$ & $0 / 6$ \\
\hline A. viridis $\mathrm{L}$. & Green amaranth & 8 & $0 / 8$ & $0 / 8$ & $0 / 8$ & $0 / 8$ \\
\hline \multicolumn{7}{|l|}{ Chenopodiaceae } \\
\hline Chenopodium murale L. & Pig weed & 16 & $2 / 16$ & $0 / 16$ & $0 / 16$ & $2 / 16$ \\
\hline C. novopokrovskyanum (Aellen) Votila & Pig weed & 3 & $0 / 3$ & $0 / 3$ & $0 / 3$ & $0 / 3$ \\
\hline \multicolumn{7}{|l|}{ Boraginaceae } \\
\hline Heliotropium europaeum L. & European heliotrope & 2 & $0 / 2$ & $1 / 2$ & $2 / 2$ & $0 / 2$ \\
\hline Heliotropium sp. & & 2 & $0 / 2$ & $0 / 2$ & $0 / 2$ & $0 / 2$ \\
\hline \multicolumn{7}{|l|}{ Malvaceae } \\
\hline Malva neglecta Wallr. & Common malva & 14 & $0 / 14$ & $0 / 14$ & $2 / 14$ & $2 / 14$ \\
\hline Alcea sp. & & 2 & $0 / 2$ & $0 / 2$ & $0 / 2$ & $0 / 2$ \\
\hline \multicolumn{7}{|l|}{ Compositae } \\
\hline Sonchus oleraceus L. & Sowthistle & 1 & $0 / 1$ & $0 / 1$ & $0 / 1$ & $0 / 1$ \\
\hline \multicolumn{7}{|l|}{ Convolvulaceae } \\
\hline Convolvulus arvensis L. & Bind weed & 4 & $0 / 4$ & $0 / 4$ & $0 / 4$ & $0 / 4$ \\
\hline Echinochloa colonum (L.) Link & Corn panic grass & 3 & $0 / 3$ & $0 / 3$ & $0 / 3$ & $0 / 3$ \\
\hline Brassica sp. & & 2 & $0 / 2$ & $0 / 2$ & $1 / 2$ & $0 / 2$ \\
\hline \multicolumn{7}{|l|}{ Rubiaceae } \\
\hline Galium aparine $\mathrm{L}$. & Cleavers & 3 & $0 / 3$ & $1 / 3$ & $0 / 3$ & $0 / 3$ \\
\hline \multicolumn{7}{|l|}{ Polygonaceae } \\
\hline Rumex sp. & Garden sorrel & 2 & $0 / 2$ & $0 / 2$ & $0 / 2$ & $0 / 2$ \\
\hline Total & & 102 & $4 / 102$ & $4 / 102$ & $5 / 102$ & $6 / 102$ \\
\hline
\end{tabular}

a Enzyme-linked immunosorbent assay was used for detection of viruses in weeds. Shown are number of infected plants/total number of weed plants tested. TMV = Tomato mosaic virus $; \mathrm{PVY}=$ Potato virus $Y ; \mathrm{CMV}=$ Cucumber mosaic virus; $\mathrm{TSWV}=$ Tomato spotted wilt virus . 
Baluchestan provinces (22). However, plants that tested positive for TYLCV in the present survey were only from SistanBaluchestan province. TYLCV has a broader host range than other whiteflytransmitted geminiviruses, which includes some weed species (40). BCTV, the other geminivirus identified, was also low in incidence and was restricted largely to the Minabe and Khash regions in Hormozgan and Sistan-Baluchestan provinces, respectively. However, a relatively high incidence of this virus occurred in greenhouses in the Zarand area in Kerman province. BCTV has been reported on sugar beet, tomato, alfalfa, cucumber, bean, and 11 weed species in regions of this province and other regions of Iran $(20,23)$. CMV and TSWV are known to occur in field- and greenhouse-grown cucurbit plants and many other plants and weeds in different provinces of Iran $(34,42)$. TMV and ToMV also have been recognized as important viruses infecting tomato and other crops in Iran $(2,30)$. In this survey, TYLCV was also detected in field and greenhouse-grown tomato plants. This result is consistent with those of Behjatnia et al. and Hajimorad et al. $(7,22)$, who observed TYLCV in Sistan-Baluchestan province.

The incidence of CMV, PVX, PVY, ToMV, and Tomato yellow top virus (TYTV) in tomato fields in Pakistan, neighboring the southeastern region of Iran, were found to be 0 to $3.3 \%, 2.6$ to $16.7 \%, 0.4$ to $13.8 \%, 26.1$ to $41.3 \%$, and 1.7 to $11.3 \%$, respectively. All viruses except TYTV were also detected from weed species in tomato fields or in the nearby areas (3). In the southeastern and central regions of Iran, however, CMV appeared to be the second most prevalent virus, and PVX and TYTV were not investigated at all. The two tobamoviruses (TMV and ToMV) occurred in about $44 \%$ of the regions, with the highest incidence of each in the Minabe region.

Mixed infections of two or three viruses were observed, with eight of the nine viruses (except for TYLCV and TcSV) (Table 1). The synergistic effects of mixed infections are of concern for tomato yield (37). This was not a subject of the present study, but it may be worth examining in future studies.

Since weed management is practiced effectively in all greenhouses, weed samples intended for evaluation as over seasoning hosts were collected from areas around the greenhouses or in the fields. Among the weed species encountered, Chrozophora heirosolymitana, C. murale, and M. neglecta were most abundant, and were infected with either CMV, TMV, or TSWV in the fields (Table 3). These and other weed species may serve as potential inoculum sources for infection of field-grown tomato plants. Chatzivassiliou et al. (11) reported 13 weed species in eight families and 19 species in 12 families near tobacco fields in Greece; most of those infected with PVY and CMV, respectively, were symptomless. Infection of 52 weed species among tobacco crops in Greece with TSWV was also confirmed (10). Weed species with and without viruslike symptoms collected from pepper fields in southern Illinois were found infected with CMV (24). In this survey, all infected weed plants were symptomless while infected with CMV, PVY, TMV, and TSWV.

In the present study, a few tomato plants and weeds, while reacting positively in ELISA for PVS, tested negative by mechanical inoculation to $N$. debnyi and by RT-PCR (data not shown). Since $N$. debnyi is a diagnostic and propagation host plant for PVS (33), these weeds and tomato plants may not be infected by PVS, but possibly by a carlavirus serologically related to PVS.

A percentage of samples from symptomatic tomato plants analyzed did not react with the antisera against any of the 14 viruses. The absence of positive reactions may be due to infection of the plants with other viruses, such as AMV, PCSV, EMDV, or an as yet unidentified virus present in the southeastern and central regions of Iran. AMV, PCSV, and EMDV were once described as infecting tomato in some regions of Iran $(13,19,30)$, but they were not included in the survey due to lack of available antiserum.

The 3-year survey of field and greenhouse-grown tomatoes showed that virus infections should be of special concern in the southeastern and central regions of Iran. They may become a serious threat to the production of tomato as a major winter crop in the fields and greenhouses of the Southeast, where a great proportion of the Iranian tomato crop is produced annually during the cooler seasons. Although insecticides are regularly used for vector and pest control in tomato fields and greenhouses, other more environmentally friendly control measures including better control of weed hosts and development and use of resistant cultivars tolerant to the predominant, economically significant viruses should be practiced.

\section{ACKNOWLEDGMENTS}

This research was supported by a grant from the Department of Environmental Science, International Center for Sciences High Technology and Environmental Science, Kerman, Iran. We thank officers of the regional agricultural services for their help in conducting the surveys, and P. Jones for kindly providing CMV, ToMV, and PVS antisera

\section{LITERATURE CITED}

1. Ahoonmanesh, A., Alavi, V., and Mosahebi, Gh. 1997. Concurrent presence of cucumber mosaic virus serotypes in certain tomato growing areas of Iran. Iran. J. Plant Pathol. 33:3-4.

2. Ahoonmanesh, A., Bahar, M., and Ghobadi, C. 1992. Tomato mosaic virus in Iran. Iran. J. Plant Pathol. 28:1-4.

3. Ali, A., and Hassan, S. 2002. Viruses infecting winter tomato crops in the North West Frontier province of Pakistan. Aust. J. Agric. Res. 53:333-338

4. Amin, P. W., Reddy, D. V. R., Ghanekar, A. M., and Reddy, M. S. 1981. Transmission of tomato spotted wilt virus, the causal agent of bud necrosis of peanut by Scirtothrips dorsalis and Frankliniella schultzei. Plant Dis. 65:663-665.

5. Aramburu, J., Galipienso, L., and Matas, M. 2006. Characterization of potato virus $\mathrm{Y}$ isolates from tomato crops in northeast Spain. Eur. J. Plant Pathol. 115:247-258.

6. Bananej, K., Shahraeen, N., Ahoonmanesh, A Lesemann, D. E., and Shahriary, D. 1998 Identification of Tomato spotted wilt virus from tomato fields in Varamin areas. Iran. J. Plant Pathol. 34:1-2.

7. Behjatnia, S. A. A., Izadpanah, K., Dry, I. B., and Rezaian, M. A. 2004. Molecular characterization and taxonomic position of the Iranian isolates of tomato leaf curl virus. Iran. J. Plant Pathol. 40:77-94.

8. Bennett, C. W. 1971. The curly top disease of sugar beet and other plants. Am. Phytopathol. Soc. Monogr. No. 7, 1-81.

9. Boonham, N., Walsh, K., Hims, M., Perston, S., North, J., and Barker, I. 2002. Biological and sequence comparisons of potato virus $Y$ isolates associated with potato tuber necrotic ringspot disease. Plant Pathol. 51:117-126.

10. Chatzivassiliou, E. K., Boubourakas, I., Drossos, E., Eleftherohorinos, I., Jenser, G., Peter, D., and Katis, N. I. 2001. Weeds in greenhouses and tobacco fields are differentially infected by Tomato spotted wilt virus and infested by its vector species. Plant Dis. 85:4046.

11. Chatzivassiliou, E. K., Efthimious, K., Drossos, E., Papadopoulou, A., Poimenidis, G., and Katis, N. I. 2004. A survey of tobacco viruses in tobacco crops and native flora in Greece. Eur. J. Plant Pathol. 110:1011-1023.

12. Clark, M. F., and Adams, A. N. 1977. Characteristics of micro plate method of enzymelinked immunosorbent assay for the detection of plant viruses. J. Gen. Virol. 34:475-483.

13. Danesh, D., Bahar, M., Ahoonmanesh, A., and Ghobadi, C. 1989. Some new hosts of potato chlorotic stunt virus in Isfahan. Page 168 in: Proc. Plant Prot. Congr. 9th, Mashhad, Iran.

14. De Avila, A. C., de Huguenot, C. R., O., Resende, E. W., Kitajima, R. N., and Goldbach, D. 1990. Serological differentiation of 20 isolates of tomato spotted wilt virus. J. Gen. Virol. 71:2801-2807.

15. Dewey, R. A., Semorile, L. C., and Grau, O. 1996. Detection of tospovirus species by RTPCR of the N-gene and restriction enzyme digestions of the products. J. Virol. Methods 56:19-26.

16. Fadaei Tehrani, A. 2003. Morphological and taxonomical studies of Longidoroidea and Dorylaimoidea super families in Iran. Ph.D. thesis. Tehran University, Tehran, Iran.

17. F.A.O. 2005. F.A.O. Statistical Databases: Agricultural data. http://faostat.fao.org.

18. Garcia-Arenal, F., Escriu, F., Aranda, M. A., Alonso-Prados, J. L., Malpica, J. M., and Fraile, A. 2000. Molecular epidemiology of cucumber mosaic virus and its satellite RNA. Virus Res. 71:1-8.

19. Ghorbani, S. 1993. Identification of tomato vein yellowing virus (TVYV) in Tehran province. Page 158 in: Proc. Plant Prot. Congr. 11th, Rashat, Iran

20. Gibson, K. E. 1967. Possible incidence of curly top in Iran: A new record. Plant Dis. Rep. 51:976-977.

21. Golnaraghi, A. R., Shahraeen, N., Pourrahim, R., Farzadfar, Sh., and Ghasemi, A. 2004. Occurrence and relative incidence of viruses infecting soybeans in Iran. Plant Dis. 88:10691074.

22. Hajimorad, M. R., Khery-Pour, A., Alavi, V., Ahoonmanesh, A., Bahar, M., Rezaian, M. A., 
and Gronenborn, B. 1996. Identification of whitefly transmitted tomato yellow leaf curl geminivirus from Iran and a survey of its distribution with molecular probes. Plant Pathol. 45:418-425.

23. Heydarnejad, J., Hosseini Abhari, E., Block Yazdi, H. R., and Massumi, H. 2007. Curly top of cultivated plants and weeds and report of a unique Curtovirus from Iran. J. Phytopathol. 155:321-325.

24. Hobbs, H. A., Eastburn, D. M., D’Arcy, C. J., Kindhart, J. D., Masiunas, J. B., Voegtlin, D. J., Weinzierl, R. A., and McCoppin, N. K. 2000. Solanaceous weeds as possible sources of Cucumber mosaic virus in southern Illinois for aphid transmission to pepper. Plant Dis. 84:1221-1224.

25. Hollings, M., and Stone, O. M. 1971. Description of Plant Viruses No. 79. Commonwealth Mycological Institute, Ferry Lane, Kew, Surrey, England.

26. Hristova, D., Karadjvoa, O., Yankulova, M., Heinze, C., and Adam, G. 2001. A survey of tospoviruses in Bulgaria. J. Phytopathol. 149:745-749.

27. Hubschen, J., Kling, L., Ipach, U., Zinkernagel, V., Bosselut, N., Esmengaud, D., Brown, D. J. F., and Neilson, R. 2004. Validation of the specificity and sensitivity of species-specific primers that provide a reliable molecular diagnostic for Xiphinema diversicaudatum, X. index, and $X$. vuittenezi. Eur. J. Plant Pathol. 110:779-788, 2004.

28. Jones, J. B., Jones, J. P., Stall, R. E., and Zitter, T. A., eds. 1991. Compendium of Tomato Disease. American Phytopathological Society, St. Paul, MN.

29. Kobatake, H., Osaki, T., and Inouye, T. 1984. The vector and reservoirs of tomato spotted wilt virus in Nara Prefecture. Ann. Phytopathol. Soc. Jpn. 50:541-544.

30. Koohi-Habibi, M., Mosahebi, G., and Okhovat, M. 1998. Identification of viruses infecting tomato in Varamin. Page 195 in: Plant Prot. Congr., 13th, Karaj, Iran

31. Kowalska, A. 1977. Reaction of red kidney bean to potato virus S. Potato Res. 20:85-88

32. Lemmetty, A., and Linqvist, I. 1993. Thrips tabaci (Lind.) (Thysanoptera) (Thripidae), another vector of tomato spotted wilt in Finland. Agric. Sci. Finl. 2:89-194.

33. Mackenzie, D. J., and Tremaine, J. H. 1990. Transgenic Nicotiana debneyii expressing viral coat protein are resistance to Potato Virus $S$. J. Gen. Virol. 71:2167-2170.

34. Massumi, H., Samei, A., Hosseini Pour, A., Shaabanian, M., and Rahimian, H. 2007. Occurrence, distribution, and relative incidence of seven viruses infecting greenhouse-grown cucurbits in Iran. Plant Dis. 91:159-163.

35. Mowat, W. P., and Dawson, S. 1987. Detection of plant viruses by ELISA using crude sap extracts and unfractionated antisera. J. Virol. Methods 15:233-247.

36. Murant, A. F. 1970. Arabis mosaic virus. CMI/AAB Description of plant viruses. No. 16. Association of Applied Biologists, Wellesbourne, UK.

37. Navatel, J. C., Trapateau, M., and Marchoux, G. 1983. La premonition: Methode deprotection des cultures contre le virus. Bilan de la lutte contre la mosaique du tabac. Quelques perspectives nouvelles. Pages 36-42 in: C.R.Col. ACTA Faune et flore auxiliaries en agriculture. Paris, May 1983.

38. Obermeier, C., Sears, J. L., Liu, H. Y., Schlueter, K. O., Ryder, E. J., Duffus, J. E., Koike, S. T., and Wisler, G. C. 2001. Characterization of distinct tombusviruses that cause diseases of lettuce and tomato in the western United States. Phytopathology 91:797-806.

39. Olusegun, S. B., Leixin, X. U., Tohru, T., and Daijiro, H. 2002. Effects of single and double infections with Potato virus $\mathrm{X}$ and Tobacco mosaic virus on disease development, plant growth, and virus accumulation in tomato. Fitopatol. Bras. 27:241-248.

40. Polston, J. E., and McGovern, R. J., and Brown, L. G. 1999. Introduction of tomato yellow leaf curl virus in Florida and implications for the spread of this and other geminiviruses of tomato. Plant Dis. 83:984-988.

41. Pourrahim, R., Ahoonmanesh, A., Farzadfar, Sh., Rakhshandehro, F., and Golnaraghi, A. R. 2004. Occurrence of Arabis mosaic virus and Grapevine leaf roll associated virus-3 on grapevines in Iran. Plant Dis. 88:424.

42. Rahimian, H., and Izadpanah, K. 1978. Identity and prevalence of mosaic inducing cucurbit viruses in Shiraz, Iran. Phytopathol. Z 92:305-312.

43. Rakhshandehroo, F., Zamani Zadeh, H. R. Modarresi, A., and Hajmansoor, S. 2006. Occurrence of Prunus necrotic ringspot virus and Arabis mosaic virus on rose in Iran. Plant Dis. 90:975.

44. Rakhshandehroo, F., Pourrahim, R., Zamani Zadeh, H., Rezaee, S., and Mohammadi, M. 2005. Incidence and distribution of virus infecting Iranian vineyards. J. Phytopathol. 153:480-484.

45. Sdoodee, R., and Teakle, D. S. 1988. Seed and pollen transmission of tobacco streak virus in omato (Lycopersicon esculentum cv. Grosse Lisse). Aust. J. Agric. Res. 39:469-474.

46. Shahraeein, N., Farzadfar, S. H., and Lesemann, D. E. 2003. Incidence of viruses infecting winter oilseed rape (Brassica napus ssp. olifera) in Iran. J. Phytopathol. 151:614-616.

47. Stance-Smith, R. 1984. Tomato ring spot virus Description of Plant Viruses No. 290. Commonwealth Mycological Institute, Ferry Lane, Kew, Surrey, England.

48. Stobbs, L. W., Broadbent, A. B., Allen, W. R. and Stirling, A. L. 1992. Transmission of tomato spotted wilt virus by the western flower thrips to weeds and native plants found in southern Ontario. Plant Dis. 76:23-29.

49. Wijkamp, I., Almarza, N., Goldbach, R., and Peters, D. 1995. Distinct levels of specificity in thrips transmission of tospoviruses. Phytopathology 85:1069-1074.

50. Williams, L. V., Lopez Lambertini, P. M. Shohara, K., and Biderbost, E. B. 2001. Occurrence and geographical distribution of tospovirus species infecting tomato crops in Argentina. Plant Dis. 85:1227-1229.

51. Zitikaite, I., Surviliene, E., and Jancys, Z 2006. Detection and characterization of a new nepovirus isolated from Lycopersicon esculen tum Mill. crop in Lithuania. Biologija 2:63-67.

52. Zitter, T. A., and Tasi, J. H. 1981. Viruses infecting tomato in Southern Florida. Plant Dis. 65:787-791. 